\title{
Analyses of the life cycle impact assessment of pharmaceutical product inventories
}

\author{
S. Boughrara, H. Aksas, N. Babakhoya, K. Louhab* \\ Laboratoire de Technologie Alimentaire - Faculty of engineer science \\ University of Boumerdes, 35000 - BOUMERDES - ALGERIA \\ "E-mail address: louhab_ka@yahoo.fr
}

Keywords: impact assessment; eco-balance; drugs; pharmaceutical

\begin{abstract}
Life cycle impact assessment (LCIA) is one of basic steps in life cycle assessment methodology (LCA). This paper presents the application of approach LCA for the rejections of drugs company SAIDAL, in order to determine the environmental impacts relative to this industrial activity, since it is classified among industry leader in the pharmaceutical field in Algeria, and that it takes part largely in the environmental disturbance by generating various categories of impacts. For this purpose, an eco-balance was establish by the collection of the theoretical data to the meadows of the company and of the practical data, resulting from the assay of pharmaceutical liquid.
\end{abstract}

\section{INTRODUCTION}

Life Cycle Assessment (LCA) is a tool to evaluate the environmental impacts of a product or process throughout its entire life cycle. LCA was first developed as a method to evaluate the impacts of a product over its entire ife cycle, but it has since grown to be used in evaluating the environmental impacts of a business activities or a nation's economic activity as well. Over the last ten years there has been a rapid expansion in the demand for LCA studies to chart the environmental performance of products. Industries, environmental experts, academics, regulatory authorities, politicians, consumers associations, environmental organizations and the general public want to know how to assess the environmental quality of products and production process. LCAs have become a common environmental management tool and a good analytical method for assessing and optimizing the environmental quality of a system over the whole life cycle.

Residues of drug for human and animals are found throughout the word. Nonetheless it was only very recently those we wearable to assay these compounds, thus proving their presence.

This has drawn the attention of environmental managers to their interactions with aquatic fauna and flora and of local water users to issues of drinking water production.

These compounds come from pharmaceutical industry reject, healthcare facilities (hospitals, clinics...), many of theme are nonetheless eliminated either by absorption or biodegradation, other pass through different barriers as; sewage treatment plants, soil... which are found in natural environment.

For this, the present study relates to application of life cycle analysis (ACV) approach to the rejection of drug company SAIDAL Algeria. In order to determine the environmental impacts relative to this industrial activity, since it's classified among industry leader in the pharmaceutical field in Algeria, and that it takes part largely in the environment disturbance by generating various category of impacts.

The assessment is done by means of LCA, according to the ISO 14040 series by using SimaPro.6 LCA Software using the Eco Indicator 95 methodology.

The objective of this study is to:

- Identify the potential environmental impact associated with the production of drug mycocide 250 (pomade) in this factory using the SimaPro.6 software. 
- Evaluate the potential impact related to a mixture of NYOMYCINE SULFATE, NYSTATINE, TRIAMCINOLONE ACETONIDE, compound of Mycocide drug and using the experience plan by SimaPro.6.

- Establish relation between potential impact and the_compound of Mycocide_drug.

\section{MATERIALS AND METHODS}

Different pomade drugs are produced in this factory, but in the case study; MYCOCIDE is selected for evaluation of potential impacts. These choose is based on the most quantity produced or commercialized in year.

Inventory data was collected for all period production of this form of drug by calculation and theoretical data taken from computer of electricity and water.

The inventory consists of a raw material usage, as well as the solid waste, liquids waste as shown below (Table 1).

The inventory data collected was calculated to quantify the inputs from the environment and outputs to the environment for every $250 \mathrm{~kg}$ produced of mycocide, this inventory is naming life cycle inventory $\mathbf{L C I}$.

The life cycle impacts assessment LCIA was conducted using the SimaPro.6 soft ware version 6.0; Eco Indicator 95 and 99 methodologies are selected to conduct the LCIA.

Table 1: Life Cycle Inventory of pomade factory.

\begin{tabular}{|c|c|}
\hline Input & Unit \\
\hline Dematerialized water & $54 \mathrm{~m}^{3} / \mathrm{J}$ \\
\hline Electricity & $933 \mathrm{M} \mathrm{WH} / \mathrm{J}$ \\
\hline Natural gas & $562 \mathrm{~N} \mathrm{~m}^{3} / \mathrm{J}$ \\
\hline Out put & unit \\
\hline Chemical oxygen demand COD & $406 \mathrm{mg} \mathrm{d} \mathrm{O} / \mathrm{l}$ \\
\hline Biological oxygen demand DBO & 163 \\
\hline Mater in suspension MES & $13 \mathrm{mg} / 1$ \\
\hline Volatile mater MVS & $2 \mathrm{mg} / 1$ \\
\hline Waste carton & $42 \mathrm{Kg} / \mathrm{J}$ \\
\hline
\end{tabular}

System boundary and functional unit: The system boundary was set to include only the production process of this drug selected (mycocide) as shown in figure 1. The society and co treatment consequence is not taking consideration in this case. The data collected has been adapted to database of the software used. The functional unit is $250 \mathrm{~kg}$ of mycocide produced by preparation.

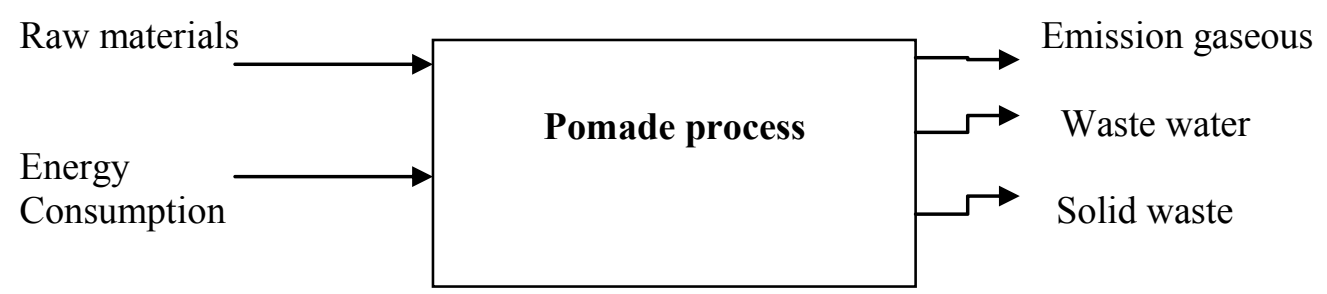

Figure 1: System Boundary of pomade process production. 


\section{RESULTS}

\section{Potential impacts of mycocide pomade}

Table 1 show the LCIA of $250 \mathrm{~kg}$ of mycocide produced in this factory. The environmental inputs to produced $250 \mathrm{~kg}$ of pomade were power consumption from turbine and grid, diesel consumption, boiler fuel, water consumption for boiler as well as process and steam input to turbine, sterilization of materiel. The outputs to the environment when $250 \mathrm{~kg}$ of pomade is produced as shown in table 1 (bilan) is various biomass, carton wastes, liquid effluent, gaseous. Figure 2 shows the single score of the LCIA of the production of $1 \mathrm{~kg}$ of mycocide drug which shows that there are only 3 potential impacts as acidification, winter smog and heavy metals expressed by $\mathrm{mPts}$ unit and figure 3 shows the whiting of the LCIA for the same production, which detect the same potential impacts.

All impacts detected have origins of the traces of principal's actives maters in the compound of this pomade, such as acidity due to $\mathrm{pH}$ of pomade, the purity of his compound, presence of minerals and heavy metals of each element.

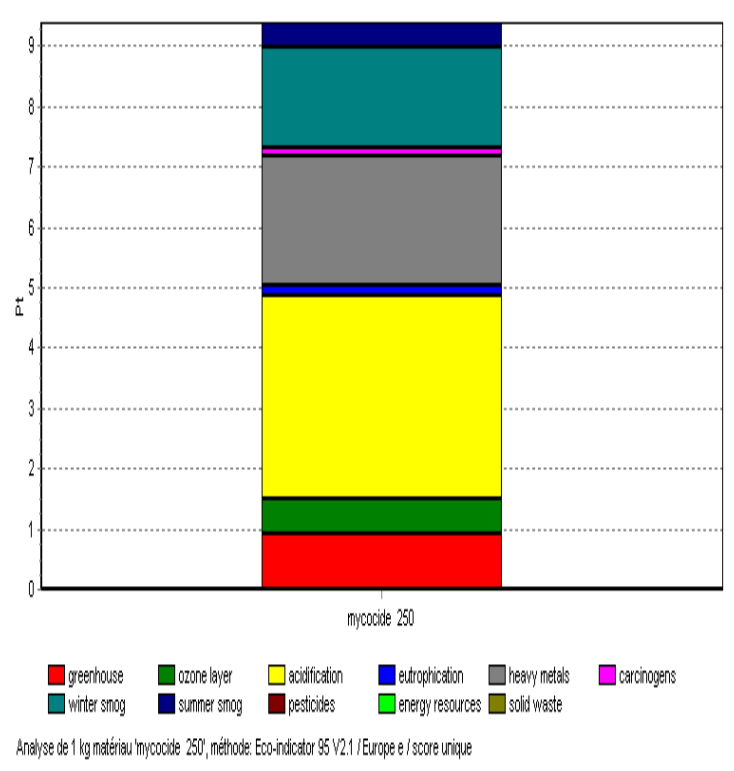

Figure2: Single score of LCIA of mycocide

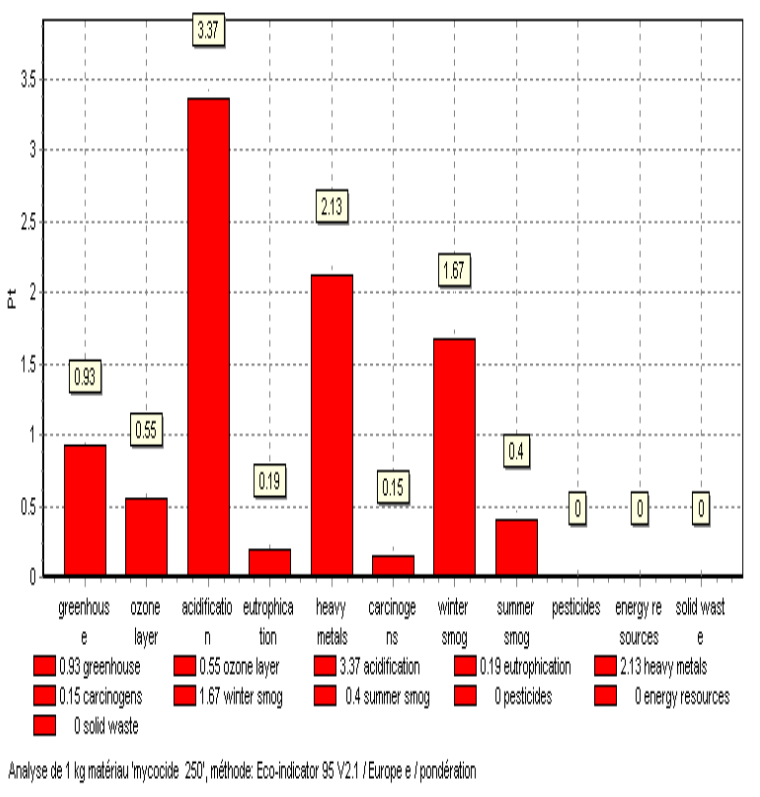

Figure 3: Whiting of LCIA of mycocide.

\section{Potential impacts of the elements composition of mycocide:}

Three (3) elements are chosen in this case with experience plan as NYSTATINE, NEOMYCINE SULFATE, and TRIAMCONOLONE ACETONIDE. The mixture of actives elements is done using the experience plan which is shown in table 2, and the concentration of actives elements is gives in the table 3.

Table.2: The mixture of actives elements using the experience plan

\begin{tabular}{|c|c|c|}
\hline Variables & X 1 & X 2 \\
\hline Number of tray & -1 & -1 \\
\hline 2 & +1 & -1 \\
\hline 3 & -1 & +1 \\
\hline 4 & +1 & +1 \\
\hline
\end{tabular}

As: $\mathrm{X}_{1}$ : is the fist variable. $\mathrm{X}_{2}$ : is the second variable.

-1 : is the low or minimum concentration. +1 : is the height or maximum concentration. 
Table 3: Mixture of principal's elements.

\begin{tabular}{|l|c|c|c|c|}
\hline \multirow{2}{*}{$\mathbf{1}^{\text {st }}$ mixture } & \multicolumn{4}{|c|}{ Composition elements (\%) } \\
\hline Nystatine (NYST) & 1 & 2.268 & 1 & 2.268 \\
\hline Triamcinolone Acetonide (TRIAM) & 0.048 & 0.048 & 0.096 & 0.096 \\
\hline $\mathbf{2}^{\text {nd }}$ mixture & \multicolumn{5}{|c|}{ Composition elements (\%) } \\
\hline Nystatine (NYST) & 1 & 2.268 & 1 & 2.268 \\
\hline Néomycine Sulfate (NEO) & 0.206 & 0.206 & 0.412 & 0.412 \\
\hline
\end{tabular}

In this step for each mixture, potentials impacts was determinate by the same software; SimaPro.6 using the EcoIndicator 99 methodology.

The LCIA of two mixtures are shown in the figures below.

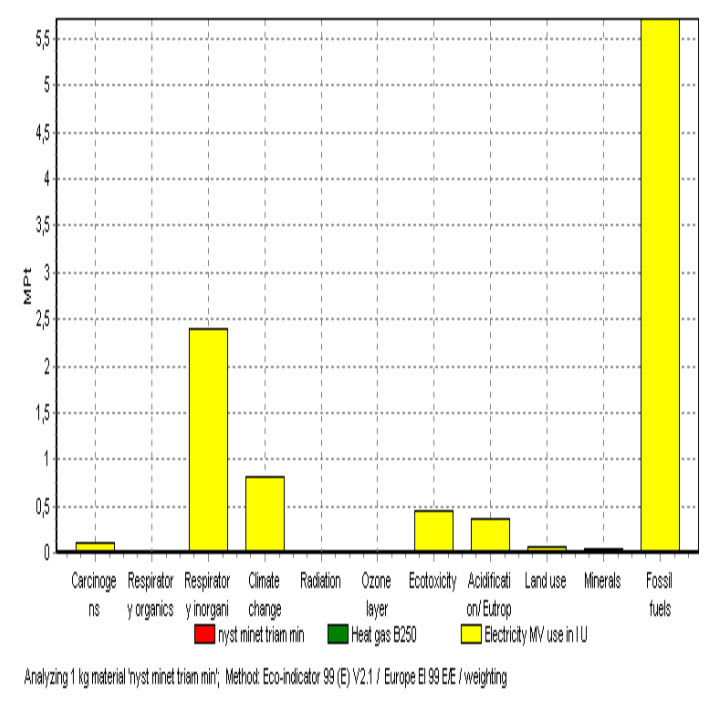

Figure 4: LCIA of mixture: Nyst min and Triam min

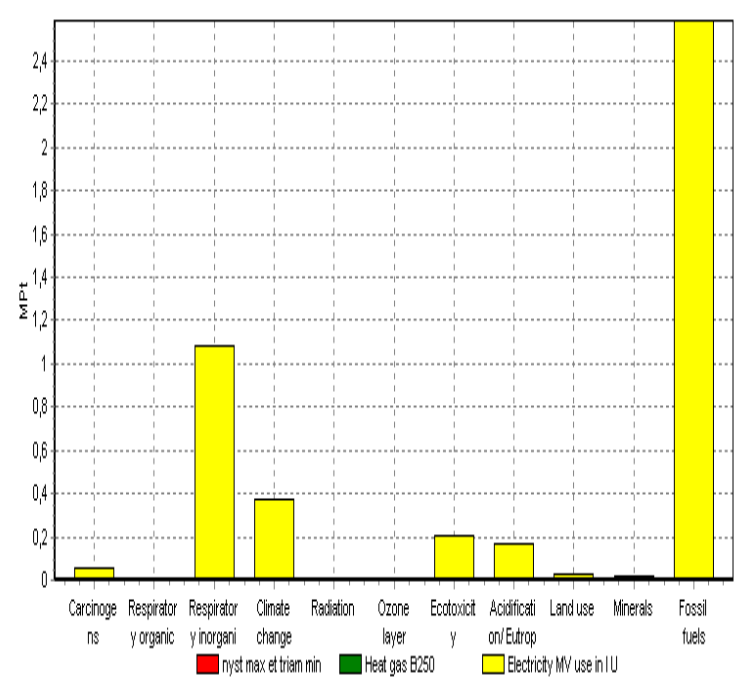

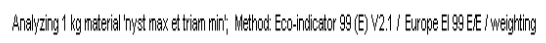

Figure 5: LCIA of mixture: Nyst max and Triam min. 


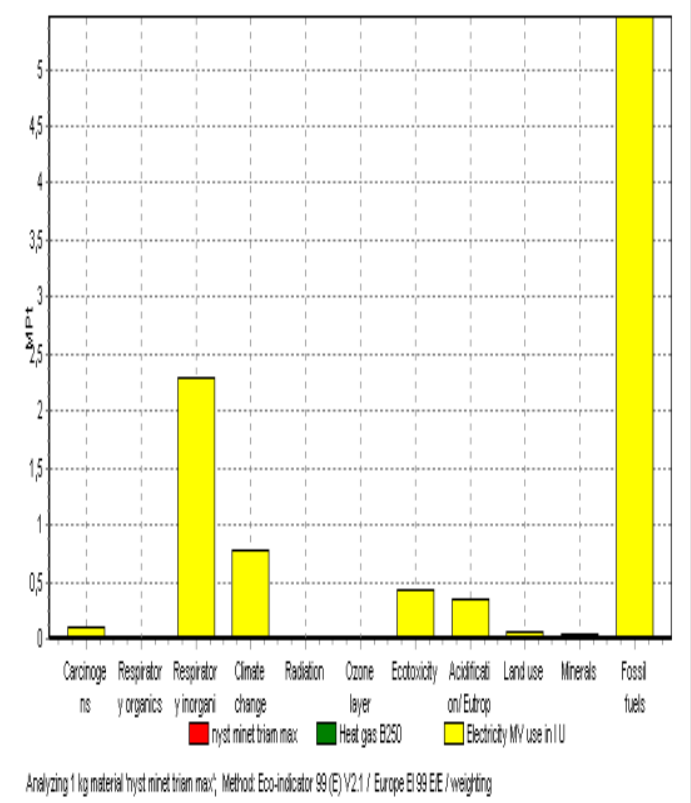

Figure 6: LCIA of mixture: Nyst min and Triam max.

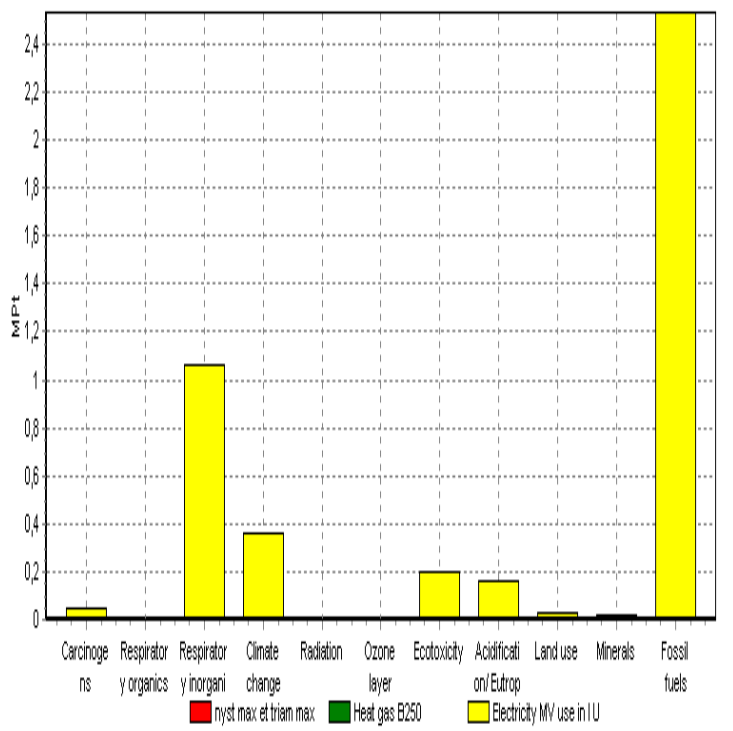

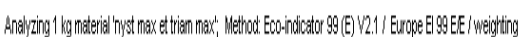

Figure 7: LCIA of mixture: Nyst max and Triam max

For each mixture, five potentials impacts ; fossil fuels, respiratory inorganic, climate change, Ecotoxicity and acidification / Eutrophisation, all these impacts are related to:

- Height consumption of natural gaz and electricity.

- Using height quantity of raw material and actives maters witch have residues in the liquid waste.

- Using organics and inorganic, acid and basic product in the process production.

Comparison potentials impacts between mixture is resumed in table 4

Table 4: Comparison potentials impacts.

\begin{tabular}{|c|c|c|c|c|c|c|c|c|}
\hline $\begin{array}{l}\text { Impacts } \\
\text { Category } \\
\text { Impacts } \\
\text { (Pts) }\end{array}$ & $\begin{array}{l}\text { Nyst } \\
\text { Min } \\
\text { Triam } \\
\text { min }\end{array}$ & $\begin{array}{l}\begin{array}{l}\text { Nyst } \\
\text { max }\end{array} \\
\text { Triam } \\
\text { min }\end{array}$ & $\begin{array}{l}\text { Nyst } \\
\text { Min } \\
\text { Triam } \\
\text { max }\end{array}$ & $\begin{array}{l}\begin{array}{l}\text { Nyst } \\
\text { Max }\end{array} \\
\text { Triam } \\
\text { max }\end{array}$ & $\begin{array}{l}\text { Nyst } \\
\text { Min } \\
\text { Neom } \\
\text { min }\end{array}$ & $\begin{array}{l}\text { Nyst } \\
\text { Max } \\
\text { Neom } \\
\text { min }\end{array}$ & $\begin{array}{l}\text { Nyst } \\
\text { Min } \\
\text { Neom } \\
\text { max }\end{array}$ & $\begin{array}{l}\text { Nyst } \\
\text { Max } \\
\text { Neom } \\
\text { max }\end{array}$ \\
\hline Carcinogen & $1.13 \mathrm{E} 5$ & $5.13 \mathrm{E} 4$ & $1.08 \mathrm{E} 5$ & $5.03 \mathrm{E} 4$ & 428 & 189 & 428 & $4.44 \mathrm{E} 4$ \\
\hline $\begin{array}{l}\text { Respiratory } \\
\text { organic }\end{array}$ & $6.8 \mathrm{E} 3$ & $3.08 \mathrm{E} 3$ & $6.5 \mathrm{E} 3$ & $3.01 \mathrm{E} 3$ & 25.6 & 11.3 & 25.6 & $2.66 \mathrm{E} 3$ \\
\hline $\begin{array}{l}\text { Respiratory } \\
\text { inorganic }\end{array}$ & $2.39 \mathrm{E} 6$ & $1.08 \mathrm{E} 3$ & $2.29 \mathrm{E} 6$ & $1.06 \mathrm{E} 6$ & $9.03 \mathrm{E} 3$ & $3.98 \mathrm{E} 3$ & $9.03 \mathrm{E} 3$ & $9.36 \mathrm{E} 5$ \\
\hline $\begin{array}{l}\text { Climate } \\
\text { change }\end{array}$ & $8.18 \mathrm{E} 5$ & $3.7 \mathrm{E} 5$ & 7.83E5 & $3.63 \mathrm{E} 5$ & 3.09E3 & $1.36 \mathrm{E} 3$ & 3.09E3 & $3.2 \mathrm{E} 5$ \\
\hline Radiation & $2.27 \mathrm{E} 3$ & $1.03 \mathrm{E} 3$ & $2.17 \mathrm{E} 3$ & $1.01 \mathrm{E} 3$ & 8.57 & 3.78 & 8.57 & 888 \\
\hline Ozone layer & $3.2 \mathrm{E} 3$ & $1.45 \mathrm{E} 3$ & $3.06 \mathrm{E} 3$ & $1.42 \mathrm{E} 3$ & 12.1 & 5.33 & 12.1 & $1.25 \mathrm{E} 3$ \\
\hline
\end{tabular}




\begin{tabular}{|l|c|c|c|c|c|c|c|c|}
\hline Ecotoxicity & $4.46 \mathrm{E} 5$ & $2.02 \mathrm{E} 5$ & $4.26 \mathrm{E} 5$ & $1.98 \mathrm{E} 5$ & $\mathbf{1 . 6 8 E 3}$ & $\mathbf{7 4 1}$ & $\mathbf{1 . 6 8 E 3}$ & $\mathbf{1 . 7 4 E 5}$ \\
\hline $\begin{array}{l}\text { Acidification/ } \\
\text { Eutrophisation }\end{array}$ & $3.64 \mathrm{E} 5$ & $1.65 \mathrm{E} 5$ & $3.48 \mathrm{E} 5$ & $1.61 \mathrm{E} 5$ & $\mathbf{1 . 3 7 E 3}$ & $\mathbf{6 0 6}$ & $\mathbf{1 . 3 7 E 3}$ & $\mathbf{1 . 4 2 E 5}$ \\
\hline Land use & $6.09 \mathrm{E} 4$ & $2.75 \mathrm{E} 4$ & $5.82 \mathrm{E} 4$ & $2.7 \mathrm{E} 4$ & $\mathbf{2 3 0}$ & $\mathbf{1 0 1}$ & $\mathbf{2 3 0}$ & $\mathbf{2 . 3 8 E 4}$ \\
\hline Minerals & $3.98 \mathrm{E} 4$ & $1.8 \mathrm{E} 4$ & $3.18 \mathrm{E} 4$ & $1.77 \mathrm{E} 4$ & $\mathbf{1 5 0}$ & $\mathbf{6 6 . 3}$ & $\mathbf{1 5 0}$ & $\mathbf{1 . 5 6 E 4}$ \\
\hline Fossil fuels & $5.71 \mathrm{E} 6$ & $2.58 \mathrm{E} 6$ & $5.46 \mathrm{E} 6$ & $2.53 \mathrm{E} 6$ & $\mathbf{2 . 1 6 E 4}$ & $\mathbf{9 . 5 E 3}$ & $\mathbf{2 . 1 5 E 4}$ & $\mathbf{2 . 2 3 E 6}$ \\
\hline
\end{tabular}

\section{CONCLUSION}

All the while environmental management was categorized more for image purposes. However in recent developments of shift towards wanting a more green earth, environmental demands are becoming marketing tools. It is becoming a determining factor for use products.

\section{References}

[1] SETAC, 1993. Guidelines for Life-Cycle Assessment: A Code of Practice. SETAC Publications, Brussels, pp:2.

[2] Stalmans, M., H. Berenbold, J. Berna, L. Cavali, A. Dillarstone, M. Franke, F. Hirsinger, D. Janzen, K. Kosswig, D. Postlethwaite, Th. Rappert, C. Renta, D. Scharer, K.P. Schick, W. Schul, H. Thomas and R. Van Sloten, 1995. European life- cycle inventory for detergent surfactants production. Munchen. Tenside Surfactant Detergent, 32: 84-85. http://cat.inist.fr/?aModele $=$ afficheN\&cpsidt $=3533603$ 